\title{
Ultrastructure, Morphology, and Sporogenesis of Pasteuria penetrans
}

\author{
Z. X. Chen, D. W. Dickson, L. G. Freitas, and J. F. Preston
}

First and second authors: Entomology and Nematology Department, University of Florida, Gainesville 32611-0620; third author: Plant Pathology Department, University of Florida, Gainesville 32611-0680; fourth author: Microbiology and Cell Science Department, University of Florida, Gainesville 32611-0700.

Accepted for publication 22 November 1996.

\begin{abstract}
Chen, Z. X., Dickson, D. W., Freitas, L. G., and Preston, J. F. 1997. Ultrastructure, morphology, and sporogenesis of Pasteuria penetrans. Phytopathology 87:273-283.

Pasteuria penetrans is a bacterial parasite of root-knot nematodes that shows great potential as a biocontrol agent. Scanning and transmission electron microscopy were used to study the ultrastructure, morphology, and sporogenesis of four isolates of $P$. penetrans. The effects of different Meloidogyne spp. and tobacco cultivars on sporangium size and morphology of endospores attached to the cuticle of second-stage juveniles (J2) of root-knot nematodes also were investigated. The $P$. penetrans isolates

P-100 from Meloidogyne sp. in Pasco County, FL; B-4 from Pratylenchus scribneri in Seminole County, FL; and P-120 from Meloidogyne spp. in Alachua County, FL. Sporangia of the four isolates were identical morphologically and similar in their dimensions, ranging from 2.39 to 3.42 $\mu \mathrm{m}$ in diameter and from 1.38 to $2.38 \mu \mathrm{m}$ in height. Different Meloidogyne spp. and tobacco cultivars had no effect on sporangium size. Endospores attached to $\mathrm{J} 2$ were visualized in three forms: endospores retaining the sporangium wall, endospores covered with a thin exosporium, and endospores without covering. Sporogenesis of $P$. penetrans was similar to that of other gram-positive bacteria and generally matched the sevenstage scheme reported for Bacillus thuringiensis.
\end{abstract} and their origins were P-20 from $M$. arenaria race 1 in Levy County, FL;
Pasteuria penetrans is a widespread mycelial and endospore-forming bacterium that has shown great potential as a biocontrol agent of plant-pathogenic nematodes $(4,6,9,34)$. $P$. penetrans has been reported on 205 nematode species belonging to 96 genera from 51 countries on 5 continents and various islands in the Atlantic, Pacific, and Indian oceans $(27,36)$. $P$. penetrans isolates have a rather limited host range and exhibit considerable morphological diversity, particularly in the size and shape of sporangia and endospores $(26,27)$.

Four species of Pasteuria have been described. P. ramosa, which parasitizes water fleas of the genus Daphnia (25), is the type species of the genus. The other three species of Pasteuria are parasites of plant-parasitic nematodes: P. penetrans on Meloidogyne spp. (26), P. thornei on Pratylenchus spp. (33), and P. nishizawae on cyst nematodes of the genera Heterodera and Globodera (31). Two other proposed new species of Pasteuria have been isolated from H. goettingiana in Münster, Germany (37) and Belonolaimus longicaudatus in Florida (13). Criteria for the differentiation of these species include size, shape, and structure of endospores and sporangia, developmental morphology of the bacterium, and host specificity $(13,29,31,33,37)$.

Individual isolates of $P$. penetrans exhibit narrow host ranges $(22,29,35)$, but the reasons for the host specificity of $P$. penetrans have not been elucidated fully $(22,35)$. Several isolates of $P$. penetrans from Florida have varying host specificity (22) and currently are being evaluated as biocontrol agents of root-knot nematodes. The objective of this experiment was to determine whether the ultrastructure of endospores and sporangia or sporogenesis among four Florida isolates of $P$. penetrans are different.

\section{MATERIALS AND METHODS}

P. penetrans isolates. The designations and origins of the $P$. penetrans isolates were P-20 from $M$. arenaria (Neal) Chitwood

Corresponding author: Z. X. Chen; E-mail address: zchen@gnv.ifas.ufl.edu

Publication no. P-1997-0121-06R

(C) 1997 The American Phytopathological Society race 1, Levy County, FL; P-100 from Meloidogyne sp., Pasco County, FL; P-120 from Meloidogyne spp., Alachua County, FL; and B-4 from Pratylenchus scribneri Steiner, Seminole County, FL (22). Isolate $\mathrm{P}-20$ was propagated on $M$. arenaria race 1 , and P-100 and B4 were propagated on $M$. incognita (Kofoid \& White) Chitwood race 1 growing on tomato (Lycopersicon esculentum Mill. 'Rutgers') in a greenhouse. Endospores of each $P$. penetrans isolate were attached separately to newly hatched second-stage juveniles (J2) of root-knot nematodes by a centrifugation technique (14). J2 with approximately five endospores attached were inoculated on potted tomato (45 to 60 days old) at a rate of 3,000 J2 per pot. Tomato plants were grown in 15 -cm-diameter pots and were provided with fertilizer and water as needed. Sporangium-filled females were harvested 55 to 60 days after inoculation. For P-120, sporangium-filled root-knot nematode females were collected from galled tobacco (Nicotiana tabacum L.) roots growing in a naturally infested field at the Green Acres Agronomy Farm, University of Florida, Gainesville.

Comparisons of sporangium size. Scanning electron microscopy (SEM) has been used routinely to determine the size of $P$. penetrans sporangia $(20,26,33)$. A modified procedure was used to prepare the samples for SEM (11). Tomato or tobacco roots $(\sim 20 \mathrm{~g}$ fresh weight) containing sporangium-filled females were incubated overnight in $100 \mathrm{ml}$ of a $12.5 \%$ cytolase PCL5 solution (Genencor International, Rochester, NY) to loosen root tissue and free rootknot nematode females. After incubation, the material was decanted onto a $600-\mu \mathrm{m}$-pore sieve nested in a $75-\mu \mathrm{m}$-pore sieve and subjected to a high-pressure water spray to dislodge the females (15). Sporangium-filled females were hand-picked with forceps with the aid of a stereomicroscope at $\times 20$. They were rinsed three times in deionized water. Individual females were ruptured with fine forceps and smeared on a $1 \times 0.5-\mathrm{cm}$ Whatman No. 1 filter paper (Whatman International, Springfield Mill, England). Filter paper containing sporangia was immediately transferred to $2 \%$ glutaraldehyde in a $0.1 \mathrm{M}$ cacodylate buffer $(\mathrm{pH} 7.2)$ and maintained overnight at $4^{\circ} \mathrm{C}$. The fixed samples were rinsed in chilled cacodylate buffer three times for 20 min each and postfixed with $2 \%$ osmium tetroxide in buffer for $2 \mathrm{~h}$ at room temperature. Samples 
were rinsed three times for 10 min each with buffer to remove the excess osmium tetroxide. Samples were dehydrated through 25, 50, 75, 95, and 100\% ethanol series, $1 \mathrm{~h}$ each. Exposure to $100 \%$ ethanol was repeated three times. After dehydration, the samples were immersed for $5 \mathrm{~min}$ in hexamethyldisilasane (Alltech Associates, Deerfield, IL), air-dried overnight in a fume hood, mounted on aluminum stubs, coated with gold, and examined with a Hitachi S-570 (Hitachi Instruments, Danbury, CT) scanning electron microscope operating at $15 \mathrm{kV}$. The height and diameter of the cup-shaped sporangium were determined from SEM photomicrographs taken using professional Polaroid $10 \times 12.5-\mathrm{cm}$ instant film no. 55 (Polaroid Corp., Cambridge, MA) or with 35-mm negative film.

Effects of nematode host and resistant crops on size of sporangia. $P$. penetrans-infected females of $M$. incognita and $M$. javanica (Treub) Chitwood were collected from a previously identified root-knot nematode-suppressive site at the Green Acres Agronomy Farm (5). The site was known to be infested with $M$.
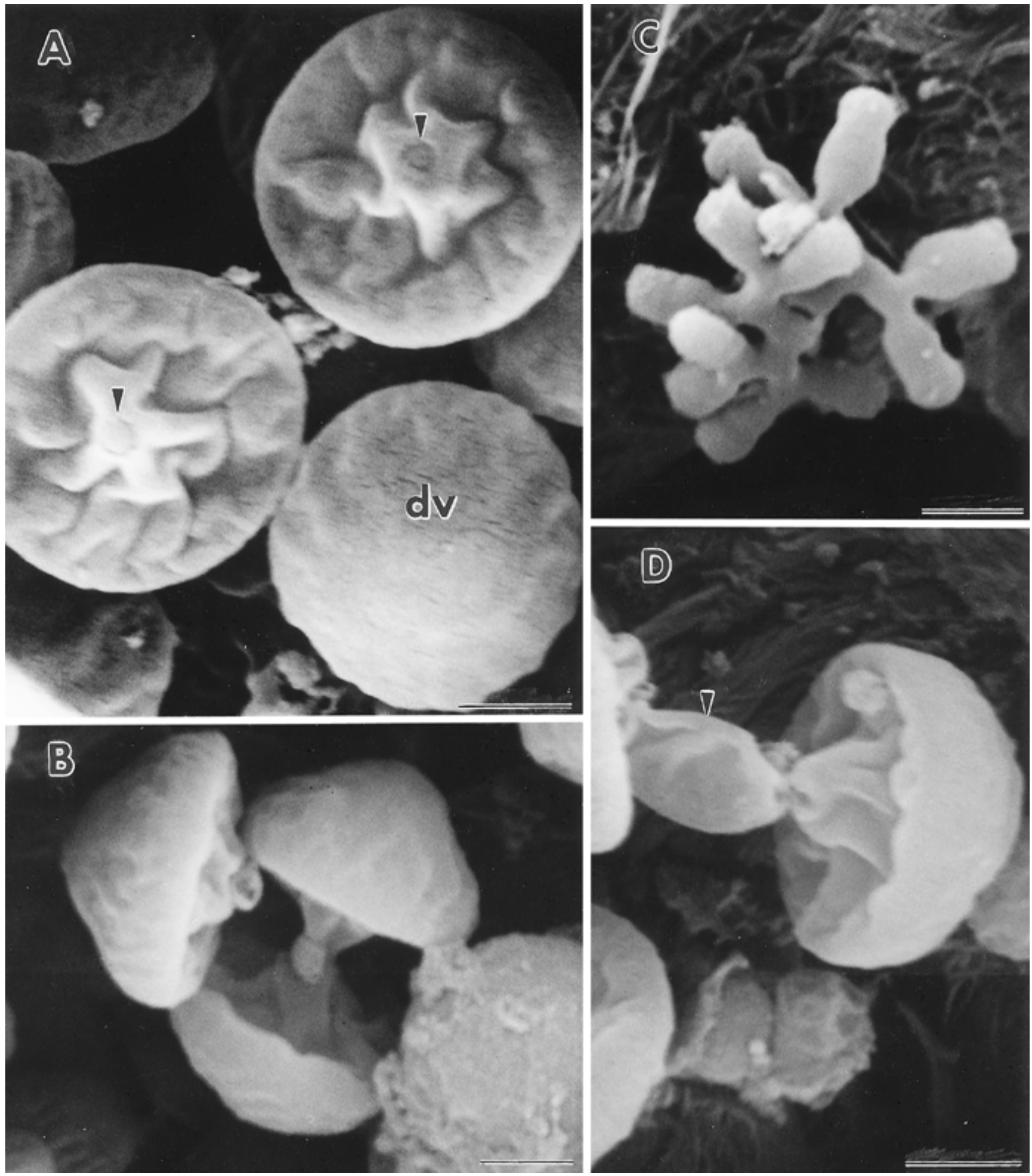

Fig. 1. Morphology of Pasteuria penetrans. Scale bars $=1 \mu \mathrm{m}$. A, Mature sporangia of P. penetrans: dorsal view (dv) of a smooth and round sporangium. Ventral view of a wrinkled sporangium with a "connection ring" (arrowheads). B, Lateral view of two connected sporangia. C, Early sporogenous stage. D, Lateral view of a sporangium connected with a degenerated sporangium or stem cell (arrowhead). 
incognita and $M$. javanica. Two $M$. incognita females and one $M$. javanica female filled with $P$. penetrans were collected from $M$. incognita-resistant tobacco cv. K326, and two $M$. javanica females and one $M$. incognita female filled with $P$. penetrans were collected from $M$. incognita-susceptible tobacco cv. Hicks. The samples were processed for SEM as described above. After each female was ruptured and smeared on filter paper, the cuticle of the female was processed for species identification based on perineal pattern (17).

Attachment of endospores to $\mathbf{J} 2$ of $M$. arenaria. Endospores of $\mathrm{P}-20$ were attached to $\mathrm{J} 2$ of $M$. arenaria race 11 day after eclosion, using a centrifugation technique (14). About $50 \mathrm{~J} 2$ with endospores attached were picked immediately with a bristle and rinsed in three changes of deionized water. The protocol previously mentioned for SEM was used to process the samples. Morphology of endospores attached to J2 was examined with a Hitachi S-570 scanning electron microscope operating at $15 \mathrm{kV}$.

Morphological comparisons of four isolates of $\boldsymbol{P}$. penetrans. Transmission electron microscopy (TEM) was used to examine the sporangium morphology of P-20, P-100, P-120, and B-4. Females containing $P$. penetrans were fixed by a microwave fixation method (19) in Karnovsky's fixative (18) in $0.1 \mathrm{M}$ cacodylate buffer ( $\mathrm{pH} 7.2)$ at $50^{\circ} \mathrm{C}$. After fixation, the material was left at room temperature for $1 \mathrm{~h}$. Nematodes were ruptured with a surgical knife to facilitate the penetration of solutes and infiltration of the plastic. The ruptured nematodes were embedded in a drop of $1 \%$ agarose at $45^{\circ} \mathrm{C}$. The nematodes were transferred to a second fixative (40) containing $2.5 \%$ glutaraldehyde and $5 \%$ dimethyl sulfoxide in $0.1 \mathrm{M}$ cacodylate buffer and kept overnight at $4^{\circ} \mathrm{C}$ (40).

The specimens were washed twice with cacodylate buffer for 30 min each and postfixed with $2 \%$ osmium tetroxide at $4{ }^{\circ} \mathrm{C}$ overnight (11). After rinsing twice in deionized water for $20 \mathrm{~min}$ each, the specimens were dehydrated in an ethanol series $(25,50,75$, and $95 \%$ and three changes of $100 \%$ ethanol, $1 \mathrm{~h}$ each). The ethanol was replaced by $100 \%$ acetone, with two changes, $30 \mathrm{~min}$ each. The specimens were infiltrated through a series of Spurr's standard resin in acetone (32): 30 and $70 \%$ and two changes of $100 \%$ resin, overnight each time. After infiltration, the specimens were oriented in plastic embedding boats containing fresh $100 \%$ resin $\sim 3 \mathrm{~mm}$ in depth and allowed to polymerize in a $60^{\circ} \mathrm{C}$ oven for $48 \mathrm{~h}$.

Ultrathin sections were cut with a glass or diamond knife on a MT 6000-XL ultramicrotome (RMC, Tucson, AZ). Gray and silver sections (50 to $70 \mathrm{~nm}$ thick) were mounted on 100-mesh copper grids coated with Formvar film and poststained in 1\% uranyl acetate for $10 \mathrm{~min}$ and in saturated aqueous lead citrate for $5 \mathrm{~min}$ (11). The specimens were examined with a JEOL 100 CX (JEOL, Tokyo) transmission electron microscope at $60 \mathrm{kV}$.

Terminology. To describe the ultrastructure of the developmental stages of $P$. penetrans, we used terms suggested by Sussman and Halvorson (38) and recently reviewed by van Iterson (39) as applied to Bacillus spp. The terminology is as follows: (i) the endospore is the single asexual spore that develops within a sporangium and is enclosed by an exosporium. Beginning from the inside and working to the outside of the endospore, (ii) the plasma membrane is the innermost layer that surrounds the central protoplast and is surrounded by (iii) the cell wall, which is usually invisible in transmission electron microphotographs. (iv) The cortex appears as a wide electron-translucent zone that surrounds the cell wall and plasma membrane; the cortex is followed outside by (v) the inner coat, a much narrower multilaminar band, and (vi) the outer coat, a wide electron-dense wall. All of these structures are surrounded by (vii) the exosporium, a delicate membrane that delineates the outermost layer of a typical gram-positive bacterial spore. Within the exosporium, Pasteuria endospores have additional structures that include (viii) the epicortical layer, which is a discontinuous, electron-dense band around the cortex that varies in appearance from species to species and (ix) the perisporium, which largely consists of peripheral fibers, which are an essential part of the Pasteuria endospore and probably involved in attachment to the nematode cuticle. The central part of the entire endospore, limited by the outer coat and distinctly differentiated from the perisporium, will be referred to as the central body (37).

\section{RESULTS}

Size and shape of sporangium. Sporangia were cup-shaped and morphologically identical among isolates (Fig. 1). Dorsal sides of sporangia were smooth and round. The ventral side was wrinkled (Fig. 1A). Occasionally, two sporangia were connected. When they were separated, a trace of a "connection ring" was revealed (Fig. $1 \mathrm{~A}$ and B). Stem cells were seldom seen in the four isolates (Fig. 1D).

The average diameter of B-4 sporangia was greater than that of other isolates $(P \leq 0.05)$ (Table 1$)$. The height of sporangia of $\mathrm{P}-120$ $(1.93 \mu \mathrm{m})$ was greater than that of P-100 $(1.74 \mu \mathrm{m})(P \leq 0.05)$. The ranges of sporangium dimensions of the isolates, however, were similar, 2.58 to $3.42 \mu \mathrm{m}$ in diameter and 1.38 to $2.38 \mu \mathrm{m}$ in height.

Effects of nematode hosts and resistant crops on size of sporangia. Diameters and heights of sporangia differed among various

TABLE 1. Diameter and height of sporangia from four isolates of Pasteuria penetrans

\begin{tabular}{lcccccccc}
\hline & \multicolumn{3}{c}{ Diameter $(\mu \mathrm{m})^{\mathrm{y}}$} & & \multicolumn{3}{c}{ Height $(\mu \mathrm{m})$} \\
\cline { 2 - 4 } \cline { 6 - 8 } Isolates $^{\mathrm{x}}$ & Average $^{\mathrm{z}}$ & $\mathrm{SE}$ & Range & & Average & SE & Range \\
\hline $\mathrm{P}-20$ & $3.10 \mathrm{~b}$ & 0.04 & $2.58-3.34$ & & $1.81 \mathrm{ab}$ & 0.05 & $1.38-2.08$ \\
$\mathrm{P}-100$ & $3.07 \mathrm{~b}$ & 0.03 & $2.78-3.21$ & & $1.74 \mathrm{~b}$ & 0.04 & $1.42-2.01$ \\
$\mathrm{P}-120$ & $3.09 \mathrm{~b}$ & 0.03 & $2.76-3.30$ & & $1.93 \mathrm{a}$ & 0.06 & $1.58-2.38$ \\
$\mathrm{~B}-4$ & $3.23 \mathrm{a}$ & 0.03 & $2.84-3.42$ & & $1.86 \mathrm{ab}$ & 0.04 & $1.58-2.13$ \\
\hline
\end{tabular}

x P-20, P-100, P-120, and B-4 originated from Meloidogyne arenaria race 1 in Levy County, Meloidogyne sp. in Pasco County, Meloidogyne spp. in Alachua County, and Pratylenchus scribneri in Seminole County, FL, respectively.

y Twenty sporangia each were measured from scanning electron photomicrographs at $\times 15,000$. Sporangia of each isolate were processed from a single female.

${ }^{\mathrm{z}}$ Means in a column followed by different letters are different $(P \leq 0.05)$ according to Duncan's multiple-range test.

TABLE 2. Diameter and height of Pasteuria penetrans isolate P-120 sporangia grown on two tobacco cultivars and two Meloidogyne species

\begin{tabular}{|c|c|c|c|c|c|c|c|}
\hline \multirow{2}{*}{$\begin{array}{l}\text { Tobacco } \\
\text { cultivar }^{\mathrm{x}}\end{array}$} & \multirow{2}{*}{$\begin{array}{c}\text { Host } \\
\text { nematode }\end{array}$} & \multicolumn{3}{|c|}{ Diameter $(\mu \mathrm{m})^{\mathrm{y}}$} & \multicolumn{3}{|c|}{ Height $(\mu \mathrm{m})$} \\
\hline & & Average $^{z}$ & $\mathrm{SE}$ & Range & Average & $\mathrm{SE}$ & Range \\
\hline Hicks & M. incognita & $3.19 \mathrm{a}$ & 0.04 & $2.96-3.39$ & $1.79 \mathrm{c}$ & 0.06 & $1.46-2.34$ \\
\hline Hicks & M. javanica & $3.09 \mathrm{a}$ & 0.03 & $2.75-3.30$ & $1.93 \mathrm{ab}$ & 0.06 & $1.58-2.38$ \\
\hline Hicks & M. javanica & $2.90 \mathrm{~b}$ & 0.05 & $2.39-3.21$ & $1.81 \mathrm{bc}$ & 0.04 & $1.54-2.09$ \\
\hline K326 & M. incognita & $2.97 \mathrm{~b}$ & 0.04 & $2.42-3.17$ & $1.82 \mathrm{bc}$ & 0.04 & $1.50-2.08$ \\
\hline K326 & M. incognita & $3.09 \mathrm{a}$ & 0.04 & $2.76-3.34$ & $1.86 \mathrm{bc}$ & 0.03 & $1.63-2.08$ \\
\hline K326 & M. javanica & $3.14 \mathrm{a}$ & 0.04 & $2.84-3.42$ & $2.02 \mathrm{a}$ & 0.03 & $1.76-2.17$ \\
\hline
\end{tabular}

${ }^{\mathrm{x}}$ Hicks is susceptible to M. incognita and K326 is resistant.

y Twenty sporangia each were measured from scanning electron photomicrographs at $\times 15,000$. Sporangia of each treatment were processed from a single female.

${ }^{\mathrm{z}}$ Means in a column followed by different letters are different $(P \leq 0.05)$ according to Duncan's multiple-range test. 
combinations of Meloidogyne species and resistant crops $(P \leq$ 0.05) (Table 2). Diameters of sporangia obtained from the three $M$. incognita females, regardless of the tobacco cultivars from which they originated, averaged $3.08 \mu \mathrm{m}$, whereas the diameter of sporangium obtained from three $M$. javanica females averaged $3.04 \mu \mathrm{m}$. The average sporangium heights also were similar, $1.82 \mu \mathrm{m}$ for sporangia from $M$. incognita females and $1.92 \mu \mathrm{m}$ for sporangia from $M$. javanica females. Sporangium diameter averaged $3.06 \mu \mathrm{m}$ for K326 and $3.07 \mu \mathrm{m}$ for Hicks. The average sporangium heights were 1.84 and $1.90 \mu \mathrm{m}$ for Hicks and K326, respectively. Maximum differences in sporangium diameters were less than $0.22 \mu \mathrm{m}$ across all treatments and less than 0.23 $\mu \mathrm{m}$ for sporangium heights (Table 2). Thus, the effects of nematode hosts and tobacco cultivars on sporangium size were negligible.

Endospores attached to $\mathbf{J} 2$. Endospores of $P$. penetrans attached along the entire body length of J2 (Figs. 2 and 3). After attachment, the sporangial wall and exosporium of most endospores sloughed off (Figs. 2 through 4), exposing the peripheral fibers and central body. Both the endospore and the central body were round (Fig. 4D). The endospores were $2.81 \pm 0.15 \mu \mathrm{m}$ in diameter. The central body was $1.58 \pm 0.05 \mu \mathrm{m}$ in diameter. Peripheral fibers appeared rough when viewed with SEM (Fig. 4C).

Three distinct forms of endospores were observed attached to the cuticle of J2. In the first form, which was rare, the endospore surface was covered by the sporangium wall (Fig. 2). In the second form, the sporangium wall sloughed off, and the surface was covered by the exosporium (Fig. 4B). In the third form, both the sporangium wall and the exosporium sloughed off to reveal the intact peripheral fibers and central body (Fig. 4C and D).

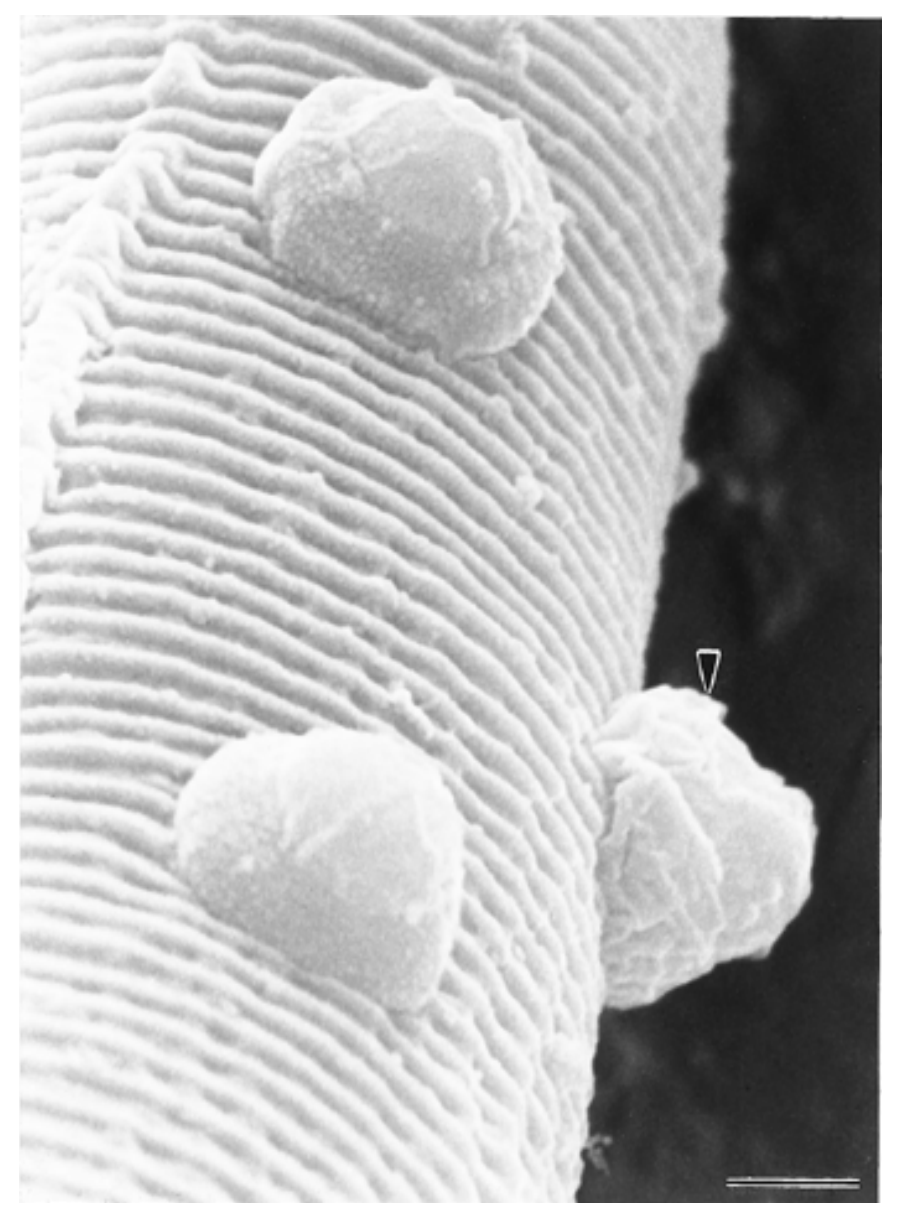

Fig. 2. Endospores of Pasteuria penetrans attached to the anterior region of a second-stage juvenile of Meloidogyne arenaria race 1. One of the endospores retains the sporangium wall (arrowhead). Scale bar $=1 \mu \mathrm{m}$.
TEM. Various developmental stages (vegetative, sporogenesis, and mature sporangia) were observed simultaneously in a single female (Fig. 5). Ultrastructure and morphology of developmental stages (mycelium and sporogenesis) of the four isolates were similar. Hyphae were septate and bounded by a $0.03-\mu \mathrm{m}$-thick wall consisting of an inner and outer membrane. The inner membrane constricted to form septations that delineate individual cells (Fig. $6 \mathrm{~A}$ and B). Septations were few in this early rapid growth stage of the microcolony (Fig. 6A). The hypha terminal was dichotomously branched. In advanced developmental stages, fragmented thalli were separated from the mycelial masses, and the terminal cell was elongated (Fig. 6B). The terminal cells increased in size and became oval (Figs. 1C and 6C), measuring 1.2 to $1.7 \mu \mathrm{m}$ long and 0.6 to $1.0 \mu \mathrm{m}$ wide and were bounded by a $0.02-\mu \mathrm{m}$-thick wall. A membrane formed about $0.4 \mu \mathrm{m}$ from the anterior end and separated the forespore from the parasporium (Fig. 6C and D). The forespore was located in the anterior end and was small compared with the parasporium. The parasporium varied in size and, in some cases, engulfed as much as two-thirds of the forespore (Fig. 6E). In these cases, the membrane was invaginated toward the cell pole, and the forespore was surrounded by an inner membrane that bounded its own protoplast and an outer membrane that bounded the mother cell's protoplast (Fig. 7A). Peripheral fibers were attached to the lower part of the forespore (Fig. 7A), and a cell wall covered the inner forespore membrane (Fig. 7B). Lamellae originated from the base and lower part of the forespore and covered the outer forespore membrane. The forespore, $1.1 \mu \mathrm{m}$ long and $0.7 \mu \mathrm{m}$ wide, had visible DNA and a $0.01-\mu \mathrm{m}$-thick boundary wall (Fig. 7C). The sporangia of this stage were egg-shaped, $2.0 \mu \mathrm{m}$ long and $1.5 \mu \mathrm{m}$ wide, and bounded by a $0.03-\mu \mathrm{m}$-thick wall.

Endospores were visible within the forespore. Endospores in the initial stage were round and $1.0 \mu \mathrm{m}$ in diameter. The protoplast of the endospore, except for the light area containing DNA, was electron dense (Fig. 7D), indicating dehydration of the endospore

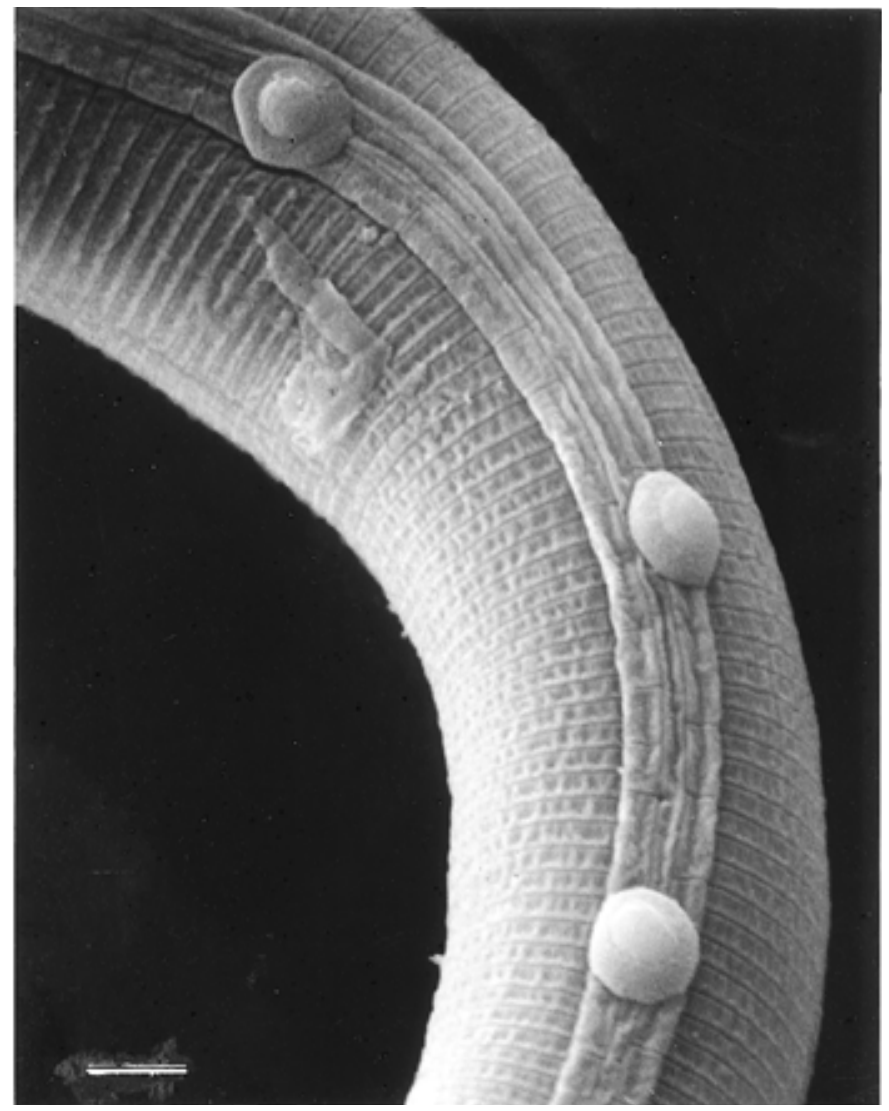

Fig. 3. Endospores of Pasteuria penetrans attached to the lateral field of a second-stage juvenile of Meloidogyne arenaria race 1 . Scale bar $=2.5 \mu \mathrm{m}$. 
protoplast. The cortex, originating underneath the multiple lamellae, was surrounded by the endospore coat (Figs. 7D and E and 8). The exosporium was the last membrane formed to cover the endospore (Fig. 7E). When the endospore matured, a basal ring surrounded the germinal pore. The epicortical layer was located between the cortex and inner coat (Fig. 9).

In a mature endospore, the cortex and outer coat were 0.13 and $0.15 \mu \mathrm{m}$ thick, respectively. Unlike the cortex, the outer coat tapered toward the basal side of the endospore and was only $0.03 \mu \mathrm{m}$ thick in the germinal pore. The germinal pore was $0.4 \mu \mathrm{m}$ in diameter and was surrounded by a basal ring texturally similar to the outer coat (Fig. 9). The central body of the endospore was ellipsoidal, $1.4 \times$ $0.9 \mu \mathrm{m}$, with the long axis lying horizontally. The epicortical layer was discontinuous and visible only on the lateral sides of the endospore. Figure 10 is a line drawing showing sporogenesis in P. penetrans.
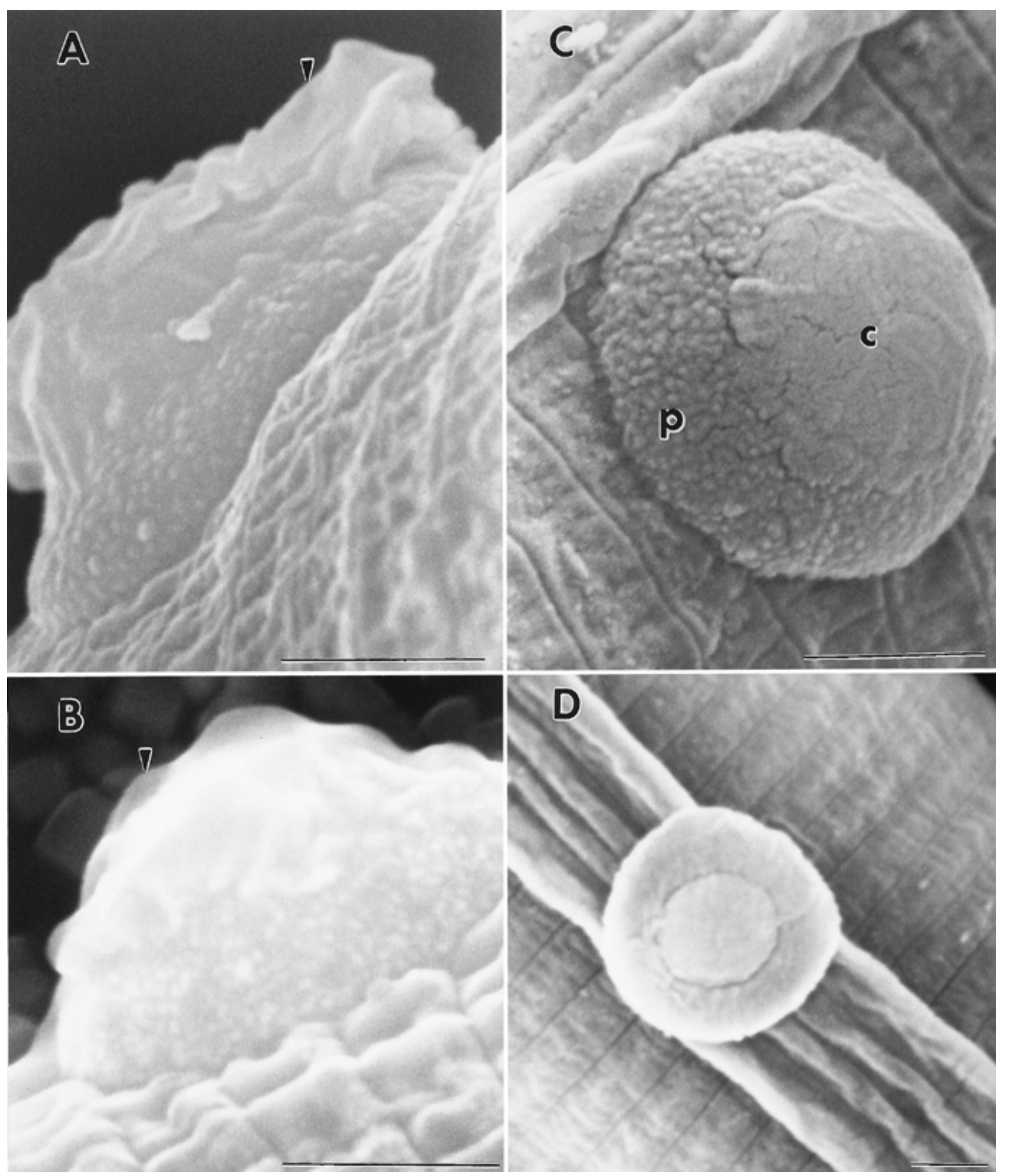

Fig. 4. Endospores of Pasteuria penetrans attached to the cuticle of second-stage juveniles of Meloidogyne arenaria race 1 . Scale bars $=1 \mu \mathrm{m}$. A, Sporangial wall and exosporium (arrowhead) sloughing off after attachment. B, Endospore with the exosporium (arrowhead). C, Both the sporangium wall and exosporium have sloughed off, revealing the peripheral fibers (p) and central body (c). D, Top view of an endospore. 


\section{DISCUSSION}

Ultrastructure, morphology, and morphometrics of sporangia were similar among the Florida isolates of $P$. penetrans. Sporangia of the four isolates were 2.58 to $3.42 \mu \mathrm{m}$ in diameter and 1.38 to $2.38 \mu \mathrm{m}$ in height, which was smaller than those reported previously (3.0 to $4.0 \mu \mathrm{m}$ in diameter and 2.26 to $2.6 \mu \mathrm{m}$ in height) (33). These differences could have been caused by the different methods used to prepare samples for electron microscopy (33). Morphology of mature sporangia of our isolates was the same as those reported for $P$. penetrans $(20,26,33)$ but different from $P$. ramosa (25), $P$. thornei (33), P. nishizawae (31), and other Pasteuria spp. (13,37).

The difference in sporangium size of our four isolates was slight but statistically different $(P \leq 0.05)$. Bird et al. (3) also found different sizes of sporangia among different isolates. We agree with their conclusion that these differences are too small to reliably differentiate various isolates.

Our isolates exhibited the same ultrastructure, morphology, and sporogenesis but differed in host specificity (22). Ciancio (7) reported that morphology and morphometrics of endospores are re-

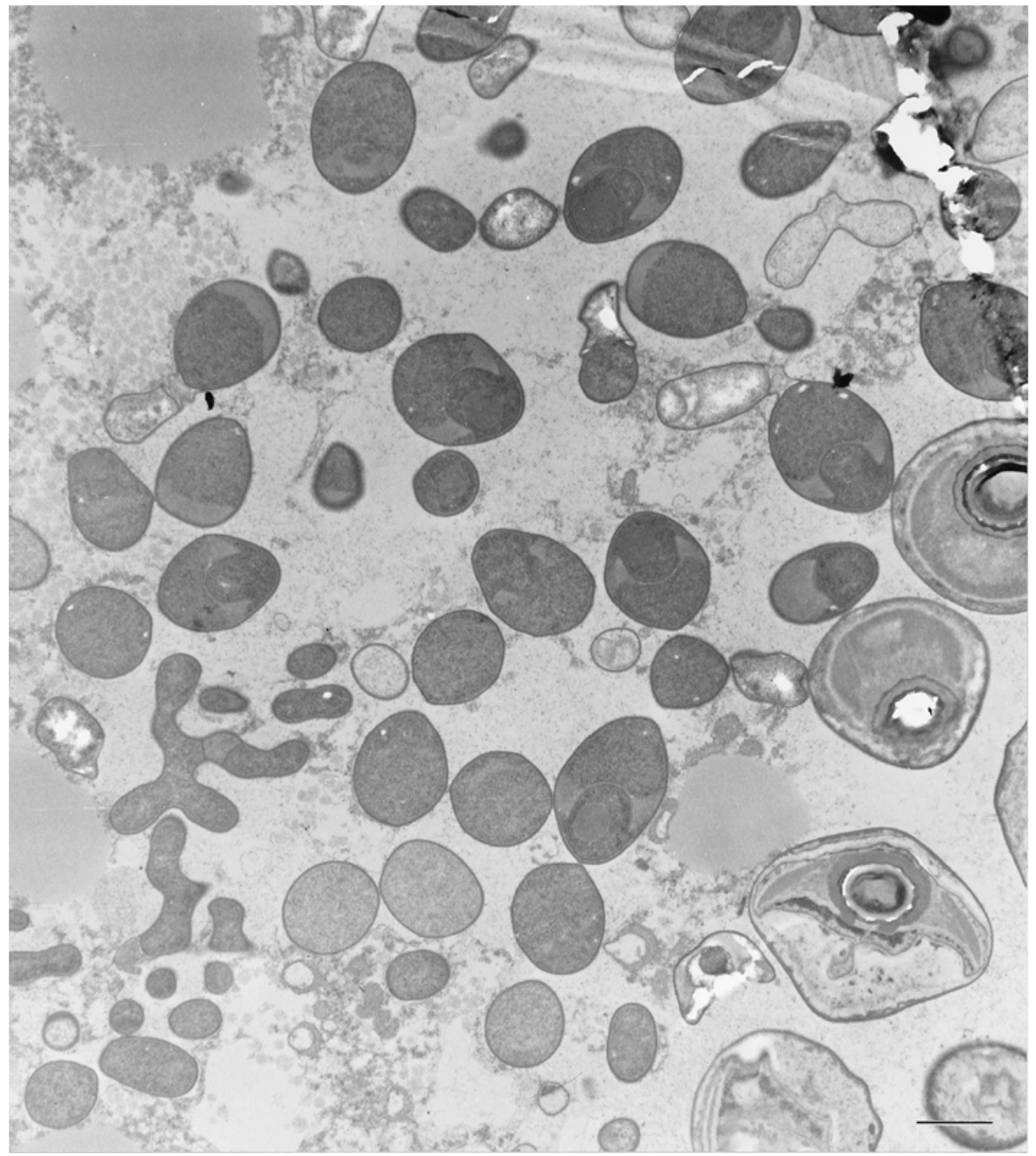

Fig. 5. Different developmental stages of Pasteuria penetrans within the pseudocoel of a single root-knot nematode female. Scale bar $=1 \mu \mathrm{m}$. 
lated to host range across nematode genera. Endospores from different nematode genera usually exhibit differences in ultrastructure, morphology, and morphometrics $(7,13,20,26,31,33,37)$. Our isolates originated from Meloidogyne spp. and Pratylenchus scribneri, but all were reared on Meloidogyne spp. Stirling (35) speculated that host specificity of $P$. penetrans might be a response to nematode populations rather than to nematode species. All the isolates reported $(22,35)$ attach to more than one Meloidogyne species or race. A recent study shows that $P$. penetrans can produce heterogeneous endospores (8). These heterogeneous subpopulations of endospores show specificity to different nematode populations. It also has been reported that endospores usually attach more readily to the nematode species on which $P$. penetrans is originally obtained or cultured than to other species $(8,22)$. Thus, the host specificity of $P$. penetrans may result from the adaptation of the bacterium to its host nematode. Such adaptations probably were not followed by changes in the ultrastructure, morphology, and morphometrics of endospores.

Two forms of endospores have been observed attached to the $\mathrm{J} 2$ of Meloidogyne spp.: endospores covered with an exosporium and bare endospores $(26,28,33)$. The exosporium in the former, however, resembles the sporangium wall in our observation. The sporangium wall is much thicker than the exosporium. The appearance
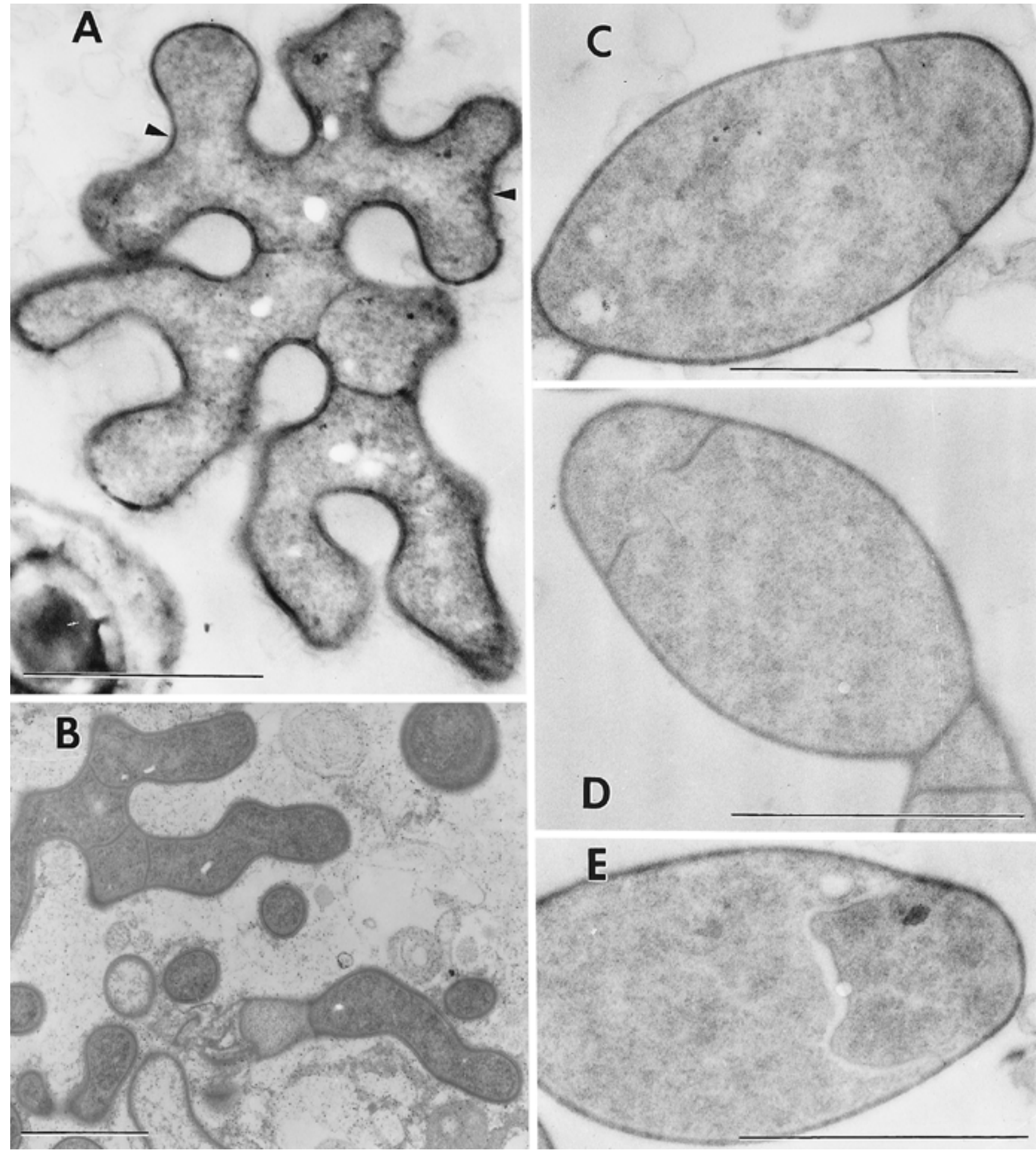

Fig. 6. Developmental stages of Pasteuria penetrans. Scale bars $=1 \mu \mathrm{m}$. A, Mycelium of P. penetrans is dichotomously branched (arrowhead). B, A microcolony in stage I in the sporogenesis of P. penetrans. C, A terminal cell in stage II in the sporogenesis of P. penetrans. D, A forespore in late stage II. E, A forespore engulfed by the parasporium in stage III. 
of the sporangium wall and exosporium is different in our scanning electron photomicrographs. The wrinkled appearance of the sporangial wall, which probably led Sayre and Starr $(26,28,33)$ to consider it the exosporium, may result from the attachment of the endospore to the $\mathrm{J} 2$ cuticle. Mature endospores usually retain their sporangial wall and exosporium. When using centrifugation to attach endospores to J2 (14), we found that most of the attached endospores were without sporangial walls. Some unknown mechanisms must be involved in the rapid sloughing off of the sporangial wall and exosporium. One possible explanation is that when the endospore descends to the nematode surface, the centrifugal force ruptures the sporangial wall and allows the endospore to contact the surface of the $\mathrm{J} 2$ cuticle. After this initial contact, the peripheral fibers conform with the $\mathrm{J} 2$ cuticle to establish a firm attachment. This process also may result in the sloughing off of the sporangial wall and exosporium because these layers are not connected to the endospore. Endospores that retain sporangial remnants probably are the intermediate or uncompleted forms of endospore attachment to $\mathrm{J} 2$.

Mesosomes were observed in $P$. penetrans $(16,20,24-28,33), P$. ramosa $(24,25,27,28,33)$, and $P$. nishizawae $(27,30)$ but not in $P$. thornei $(28,33)$ or other Pasteuria spp. $(13,30)$. We did not observe mesosomes in the four isolates studied. Mesosomes also have been observed in other bacteria (39). Based on recent evidence from
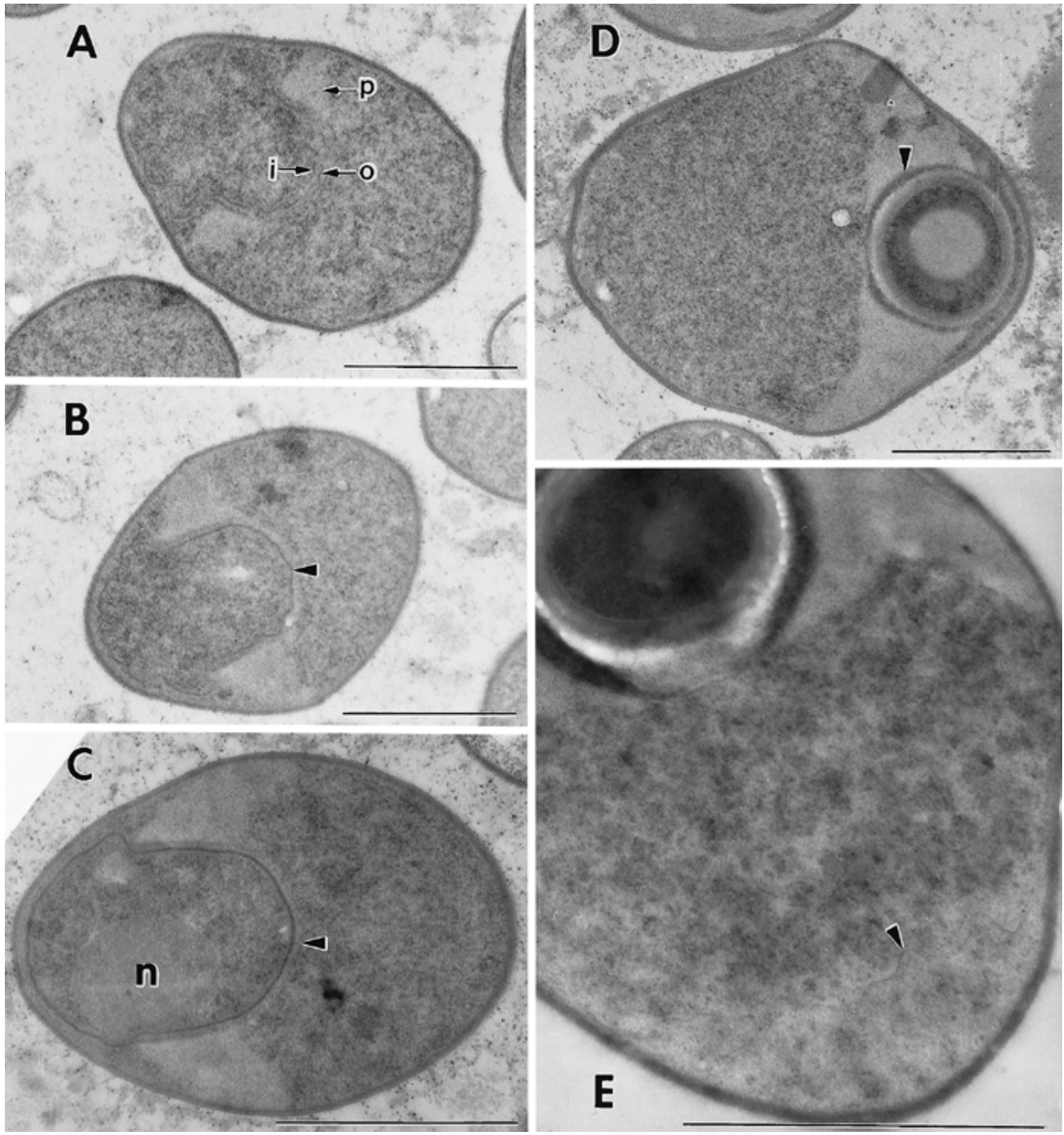

Fig. 7. Sporogenous stages of Pasteuria penetrans. Scale bars $=1 \mu \mathrm{m}$. A, The forespore is surrounded by an inner membrane (i) that bounds its own protoplast and an outer membrane (o) that bounds the mother cell's protoplast. Peripheral fibers (p) have attached to the lower part of the forespore. B, A cell wall (arrowhead) covers the inner forespore membrane in late stage III. C, Lamellae (arrowhead), which give rise to the cortex, inner coat, and outer coat of the endospore, are visible in early stage IV. The nucleoid (n) contains DNA. D, The outer coat (arrowhead) surrounds the cortex. E, Exosporium (arrowhead) has formed. 
freeze-fracture preparations, however, these internal membranous structures probably are fixation artifacts $(10,12,21)$. Moreover, a recent study has proved that suboptimum fixation conditions can create the artifact (1). These conditions include any one of the following: phosphate-buffered $2.5 \%$ glutaraldehyde, $0.1 \%$ osmium tetroxide, and $0.5 \%$ glutaraldehyde plus $2.5 \%$ formaldehyde (1). Mesosomes reported in Pasteuria spp. always associate with material fixed with 2 or $3 \%$ glutaraldehyde in phosphate buffers (16, 20,24-28,30,33). Materials freeze-fractured, freeze-substituted, or fixed in cacodylate-buffered $2.5 \%$ glutaraldehyde lack mesosomes (1).

Transmission electron micrographs in earlier studies of $P$. penetrans only showed a few stages of sporogenesis $(20,24-26,28,29$, 33). Furthermore, some previous transmission electron micrographs were difficult to interpret, e.g., an opaque area in the forespore (Fig. 5 in [26] and Fig. 33.25 in [28]). Accordingly, the line drawings reported in earlier studies represented only a portion of the sporogenesis in $P$. penetrans (26). Our results provide a more complete scenario of sporogenesis than others $(20,24-26,28,29,33)$.

The line drawings of our transmission electron micrographs reveal that sporogenesis in $P$. penetrans is similar to that of other well-studied gram-positive bacteria; here we chose Bacillus thuringiensis for comparison. The sporogenesis in B. thuringiensis has been classified into seven morphological stages (39). Stage I, defined as condensation of the replicated chromosome to form an axial filament, is not observed in $P$. penetrans. Stages II through VII are similar in Pasteuria and Bacillus and involve formation of the forespore septum (stage II); engulfment of the forespore (stage III); formation of the cortex, coat, and exosporium (stages IV through VI); and sporangium maturation (stage VII). Perisporium, termed peripheral fibers in $P$. penetrans and parasporal crystals in $B$. thuringiensis, is formed after engulfment of forespores at stage III in both organisms.

Although Pasteuria and Bacillus exhibit similar sporogenesis, they are not necessarily close relatives. Sporogenesis and ultrastructure of bacterium endospores are highly conserved (23). Sporogenesis of bacteria probably evolved only once (23). Moreover, Pasteuria

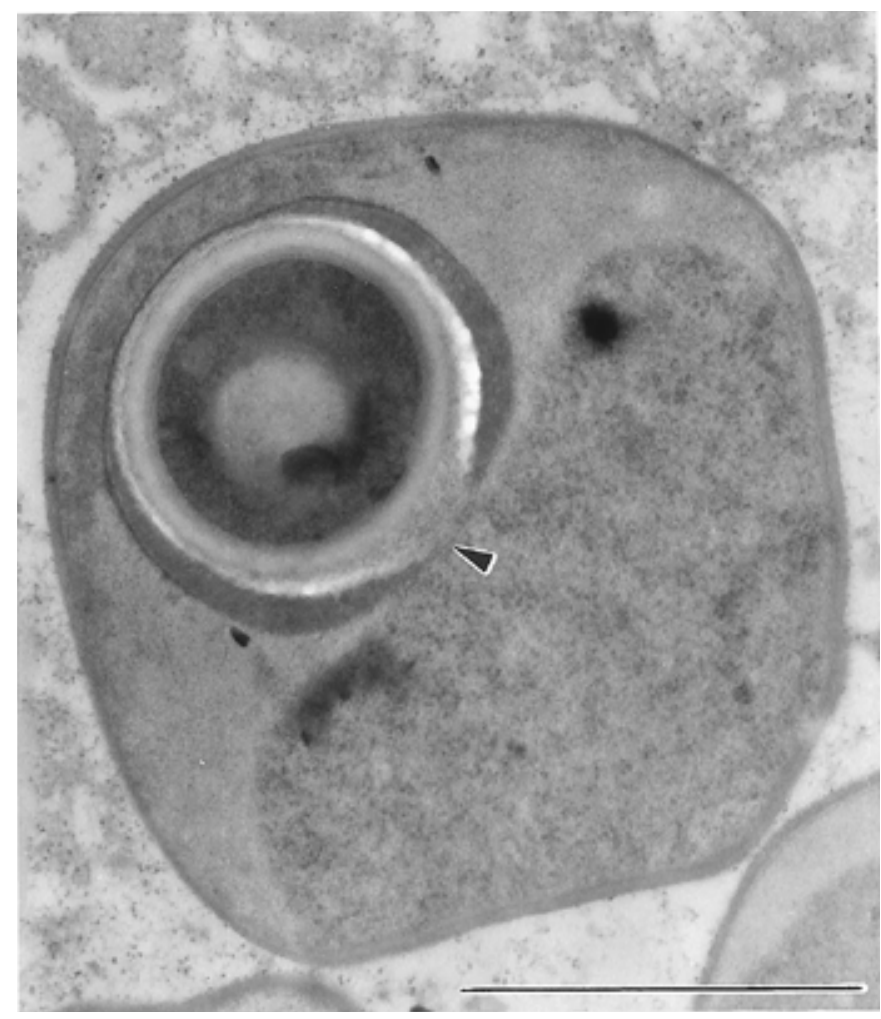

Fig. 8. Endospore of Pasteuria penetrans in the late sporogenous stage. The arrowhead indicates the position of the germinal pore of the endospore. Scale bar $=1 \mu \mathrm{m}$
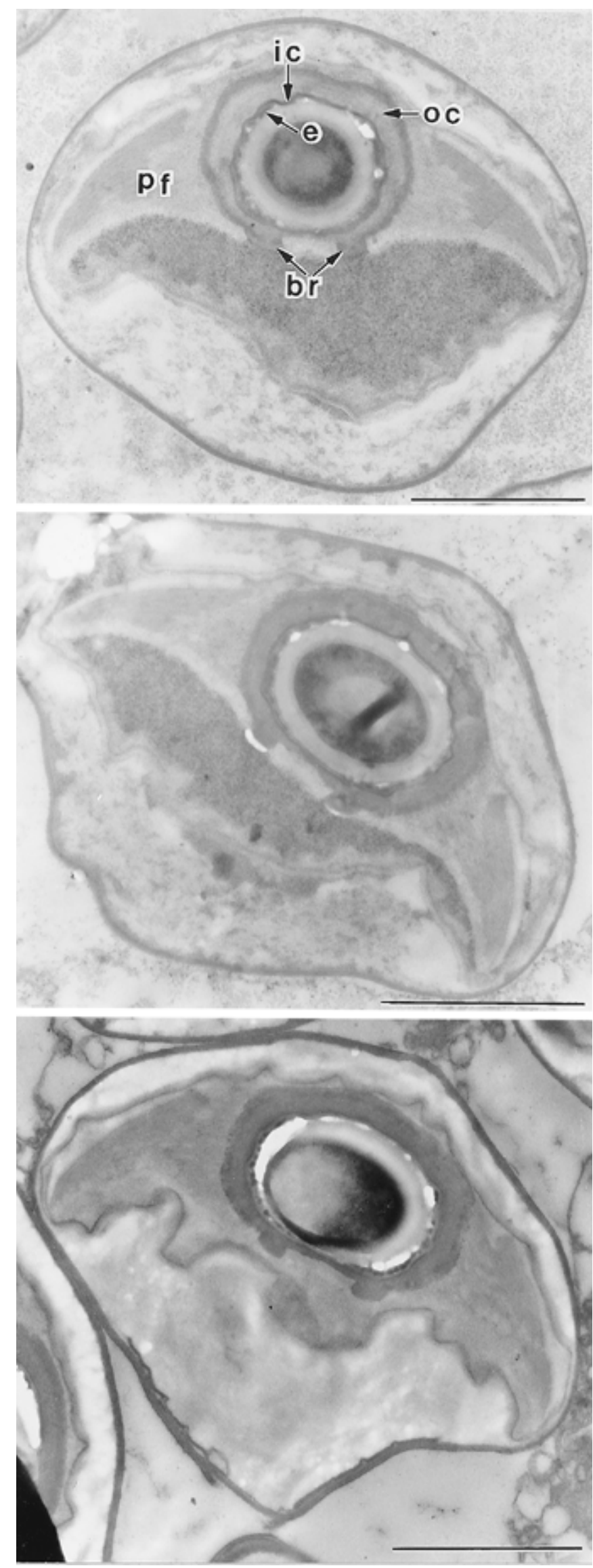

Fig. 9. Mature Pasteuria penetrans endospores (stage VII). The epicortical layer (e) is a discontinuous membrane located inside the inner (ic) and outer coats (oc). The basal ring (br) surrounds the germinal pore. The peripheral fibers (pf) allow the endospore to attach to the nematode cuticle. Scale bars $=1 \mu \mathrm{m}$. 


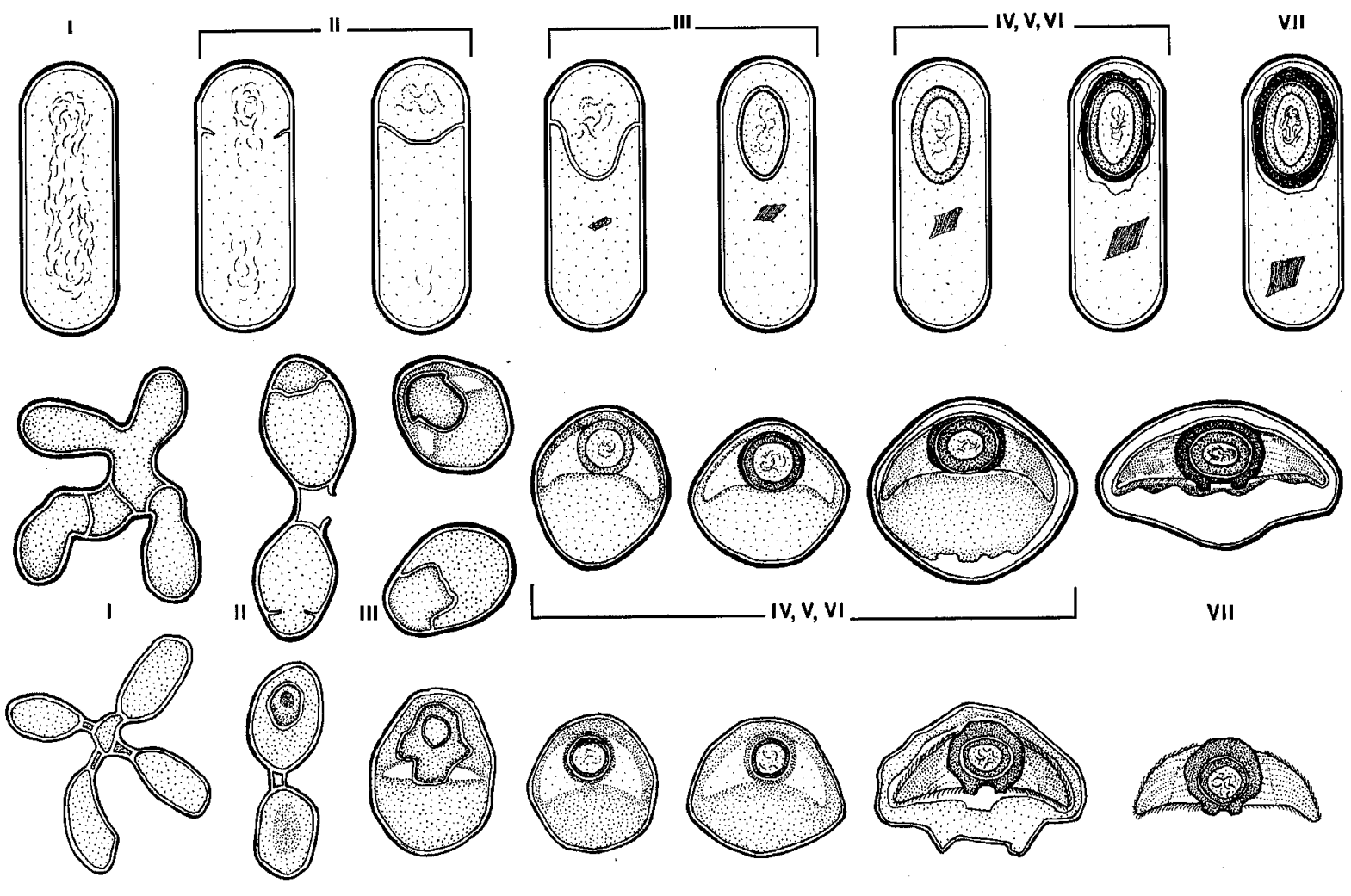

Fig. 10. Line drawing of sporogenesis in Pasteuria penetrans (middle row) compared to sporogenesis in Bacillus thuringiensis (upper row, redrawn from [39]) and previously reported sporogenesis of P. penetrans (lower row, redrawn from [26]).

and Bacillus differ in several fundamental ways. Most importantly, Pasteuria differs from Bacillus in that Pasteuria penetrates its host with a germ tube and forms thalli in the host body cavity. Because artificial cultivation of Pasteuria spp. is currently unsuccessful, the phylogenetic relationship of Pasteuria and Bacillus to other gram-positive bacteria is unknown (2).

\section{ACKNOWLEDGMENTS}

Florida Agricultural Experiment Station Journal Series R-05304. Supported in part by a grant from the Southern Region IPM: grant 93-341038396. A portion of a Ph.D. dissertation by Z. X. Chen. We thank H. C. Aldrich, R. M. Giblin-Davis, and G. C. Smart, Jr., for reviewing this manuscript, and H. C. Aldrich, H. Cromroy, B. Carpenter, and D. Williams for providing facilities and instructions for this study.

\section{LITERATURE CITED}

1. Aldrich, H. C., Beimborn, D. B., and Schonheit, P. 1987. Creation of artifactual internal membranes during fixation of Methanobacterium thermoautotrophicum. Can. J. Microbiol. 33:844-849.

2. Berkeley, R. C. W., and Ali, N. 1994. Classification and identification of endospore-forming bacteria. Pages 1-8 in: Fundamental and Applied Aspects of Bacterial Spores. G. W. Gould, A. D. Russell, and D. E. S. Stewart-Tull, eds. Blackwell Scientific Publishing, Oxford

3. Bird, A. F., Brisbane, P. G., McClure, S. G., and Kimber, R. W. L. 1990. Studies on the properties of the spores of some populations of Pasteuria penetrans. J. Invertebr. Pathol. 55:169-178.

4. Brown, S. M., Kepner, J. L., and Smart, G. C., Jr. 1985. Increased crop yields following application of Bacillus penetrans to field plots infested with Meloidogyne incognita. Soil Biol. Biochem. 17:483-486.

5. Chen, S., Dickson, D. W., and Whitty, E. B. 1994. Response of Meloidogyne spp. to Pasteuria penetrans, fungi, and cultural practices in tobacco. J. Nematol. 26:620-625.

6. Chen, Z. X., Dickson, D. W., McSorley, R., Mitchell, D. J., and Hewlett, T. E. 1996. Suppression of Meloidogyne arenaria race 1 by soil application of endospores of Pasteuria penetrans. J. Nematol. 28:159-168.

7. Ciancio, A. 1995. Phenotypic adaptations in Pasteuria spp. nematode parasites. J. Nematol. 27:328-338.

8. Davies, K. G., Redden, M., and Pearson, T. K. 1994. Endospore hetero- geneity in Pasteuria penetrans related to adhesion to plant-parasitic nematodes. Lett. Appl. Microbiol. 19:370-373.

9. Dickson, D. W., Oostendorp, M., Giblin-Davis, R. M., and Mitchell, D. J. 1994. Control of plant-parasitic nematodes by biological antagonists. Pages 575-601 in: Pest Management in the Subtropics, Biological Control-A Florida Perspective. D. Rosen, F. D. Bennett, and J. L. Capinera, eds. Intercept, Andover, England.

10. Dubochet, J., McDowall, A. W., Menge, B., Schmid, E. N., and Lickfeld, K. G. 1983. Electron microscopy of frozen-hydrated bacteria. J. Bacteriol. 155:381-390.

11. Dykstra, M. J. 1993. A Manual of Applied Techniques for Biological Electron Microscopy. Plenum Press, New York.

12. Ebersold, H. R., Cordier, J. L., and Luthy, P. 1981. Bacterial mesosomes: Method-dependent artifacts. Arch. Microbiol. 130:19-22.

13. Giblin-Davis, R. M., Williams, D., Hewlett, T. E., and Dickson, D. W. 1995. Development and host attachment studies using Pasteuria from Belonolaimus longicaudatus from Florida. (Abstr.) J. Nematol. 27:500.

14. Hewlett, T. E., and Dickson, D. W. 1993. A centrifugation method for attaching endospores of Pasteuria spp. to nematodes. J. Nematol. 25 (Suppl.):785-788.

15. Hussey, R. S. 1971. A technique for obtaining quantities of living Meloidogyne females. J. Nematol. 3:99-100.

16. Imbriani, J. L., and Mankau, R. 1977. Ultrastructure of the nematode pathogen, Bacillus penetrans. J. Invertebr. Pathol. 30:337-347.

17. Jepson, S. B. 1987. Identification of root-knot nematodes (Meloidogyne species). CAB International, Oxon, England.

18. Karnovsky, M. J. 1965. A formaldehyde-glutaraldehyde fixative of high osmolality for use in electron microscopy. (Abstr.) J. Cell Biol. 27:137A138A.

19. Login, G. R., Galli, S. J., and Dvorak, A. M. 1992. Immunocytochemical localization of histamine in secretory granules of rat peritoneal mast cells with conventional or rapid microwave fixation and an ultrastuctural post-embedding immunogold technique. J. Histochem. Cytochem. 40: 1247-1256.

20. Mankau, R. 1975. Bacillus penetrans n. comb. causing a virulent disease of plant-parasitic nematodes. J. Invertebr. Pathol. 26:333-339.

21. Nanninga, N. 1971. The mesosome of Bacillus subtilis as affected by chemical and physical fixation. J. Cell Biol. 48:219-224.

22. Oostendorp, M., Dickson, D. W., and Mitchell, D. J. 1990. Host range and ecology of isolates of Pasteuria spp. from the southeastern USA. J. Nematol. 22:525-531.

23. Priest, F. G. 1993. Systematics and ecology of Bacillus. Pages 3-16 in: 
Bacillus subtilis and Other Gram-Positive Bacteria: Biochemistry, Physiology, and Molecular Genetics. A. L. Sonenshein, J. A. Hoch, and R. Losick, eds. American Society for Microbiology, Washington, DC.

24. Sayre, R. M. 1993. Pasteuria, Metchnikoff, 1888. Pages 101-111 in: Bacillus subtilis and Other Gram-Positive Bacteria: Biochemistry, Physiology, and Molecular Genetics. A. L. Sonenshein, J. A. Hoch, and R. Losick, eds. American Society for Microbiology, Washington, DC.

25. Sayre, R. M., Gherna, R. L., and Wergin, W. P. 1983. Morphological and taxonomic reevaluation of Pasteuria ramosa Metchnikoff 1888 and " $\mathrm{Ba}$ cillus penetrans" Mankau 1975. Int. J. Sys. Bacteriol. 33:639-649.

26. Sayre, R. M., and Starr, M. P. 1985. Pasteuria penetrans (ex Thorne, 1940) nom. rev., comb.n., sp.n., a mycelial and endospore-forming bacterium parasitic in plant-parasitic nematodes. Proc. Helminthol. Soc. Wash. 52:149-165.

27. Sayre, R. M., and Starr, M. P. 1988. Bacterial diseases and antagonists of nematodes. Pages 69-101 in: Diseases of Nematodes. G. O. Poinar, Jr., and H.-B. Jansson, eds. CRC Press, Boca Raton, FL.

28. Sayre, R. M., and Starr, M. P. 1989. Genus Pasteuria Metchnikoff, 1888. Pages 2601-2615 in: Bergey's Manual of Systematic Bacteriology. S. T. Williams, ed. Williams and Wilkins, Baltimore, MD.

29. Sayre, R. M., Starr, M. P., Golden, A. M., Wergin, W. P., and Endo, B. Y. 1988. Comparison of Pasteuria penetrans from Meloidogyne incognita with a related mycelial and endospore-forming bacterial parasite from Pratylenchus brachyurus. Proc. Helminthol. Soc. Wash. 55:28-49.

30. Sayre, R. M., Wergin, W. P., Nishizawa, T., and Starr, M. P. 1991. Light and electron microscopical study of a bacterial parasite from the cyst nematode, Heterodera glycines. J. Helminthol. Soc. Wash. 58:69-81.
31. Sayre, R. M., Wergin, W. P., Schmidt, J. M., and Starr, M. P. 1991. Pasteuria nishizawae sp. nov., a mycelial and endospore-forming bacterium parasitic on cyst nematodes of the genera Heterodera and Globodera. Res. Microbiol. 142:551-564.

32. Spurr, A. R. 1969. A low-viscosity epoxy resin embedding medium for electron microscopy. J. Ultrastruct. Res. 26:31-43.

33. Starr, M. P., and Sayre, R. M. 1988. Pasteuria thornei sp. nov. and Pasteuria penetrans sensu stricto emend., mycelial and endospore-forming bacteria parasitic respectively, on plant-parasitic nematodes of the genera Pratylenchus and Meloidogyne. Ann. Inst. Pasteur Microbiol. 139:11-31.

34. Stirling, G. R. 1984. Biological control of Meloidogyne javanica with Bacillus penetrans. Phytopathology 74:55-60.

35. Stirling, G. R. 1985. Host specificity of Pasteuria penetrans within the genus Meloidogyne. Nematologica 31:203-209.

36. Sturhan, D. 1988. New host and geographical records of nematode-parasitic bacteria of the Pasteuria penetrans group. Nematologica 34:350-356.

37. Sturhan, D., Winkelheide, R., Sayre, R. M., and Wergin, W. P. 1994. Light and electron microscopical studies of the life cycle and developmental stages of a Pasteuria isolate parasitizing the pea cyst nematode, Heterodera goettingiana. Fund. Appl. Nematol. 17:29-42.

38. Sussman, A. S., and Halvorson, H. O. 1966. Spores: Their Dormancy and Germination. Harper and Row, New York.

39. van Iterson, W. 1984. Inner Structures of Bacteria. Van Nostrand Reinhold, New York.

40. Zeikus, J. A., and Aldrich, H. C. 1975. Use of hot formaldehyde fixative in processing plant-parasitic nematodes for electron microscopy. Stain Technol. 50:219-225. 